\title{
ВУЗЛОВИЙ ПІДХІД ЩОДО КАНАЛІВ РОЗПОДІЛУ
}

\author{
УЗЛОВОЙ ПОДХОД К КАНАЛАМ РАСПРЕДЕЛЕНИЯ \\ POINT APPROACH FOR THE DISTRIBUTION CHANNELS
}

Стаття фокусує увагу на важливості розроблення вузлового підходу, як підтрунтя для розроблення омні-канальних стратегій розподілу. При такому підході, канал розподілу розуміється як послідовність вузлів, по яких в результаті здійснення операції із потоками розподілу відбувається доведення продукиї (послуг) до споживача, які можуть знаходитись під контролем одного чи декількох ринкових суб'єктів. В статті систематизовано логістичні потоки та потоки розподілу за допомогою кругів Ейлера. Зазначено синтетичні потоки розподілу: фізичне володіння $i$ переміщення; право власності, сервіс, ризики, оплата, просування, контакти та переговори, оформлення замовлення. Синтетичні потоки розподілені за базовими: матеріальним, інформачійним та фінансовим. Також автором наведено схему каналів розподілу із урахуванням впливу окремих вузлів на різні стадії прочесу прийняття рішення спожсивачем про купівлю. При цьвому запропоновано додатковий етап в процесі прийняття рімення - етап оформлення замовлення споживачем.

Ключові слова: канал розподілу, логістика, матеріальний потік, інформаційний потік, фінансовий потік, потоки в каналах розподілу, система розподілу, процес прийняття рішення о купівлі, омні-канальна стратегія розподілу.

Статья фокусирует внимание на важности разработки узлового подхода, как основы для разработки омни-канальных стратегий распределения. При таком подходе, канал распределения понимается как последовательность узлов, по которым в результате совершения операций с потоками распределения происходит доведение продукиии (услуг) потребителю, которые могут находиться под контролем одного или нескольких рыночных субъектов. В статье систематизированы логистические потоки и потоки распределения с помощью кругов Эйлера. Указаны синтетические потоки распределения: физическое владение и перемещения; право собственности, сервис, риски, оплата, продвижение, контакты и переговоры, оформление заказа. Синтетические потоки распределень по базовым: материальным, информационным и финансовым. Также автором приведена схема каналов распределения с учетом влияния отдельных узлов на различные стадии процесса принятия решения потребителем о покупке. При этом предложено дополнительный этап в процессе принятия решения - этап оформления заказа потребителем.

Ключевые слова: каналы распределения, логистика, материальный поток, информационный поток, финансовый поток, потоки в каналах распределения, система распределения, процесс принятия решения о покупке, омни-канальная стратегия распределения. 
The article focuses on the importance of of developing point approach as the basis for the development of omni-channel distribution strategy. With this approach, the distribution channel is understood as a series of point making the product (service) available for consumption to consumer, as a result of the operations with the distribution flows, points can be controlled by one or more market players. In the article the logistics flows and distribution flows are systematized using Euler circles. Said synthetic distribution flows: physical possession and movement; ownership, service, risk, payment, promotion, contacts and negotiations, ordering. Synthetic flows are distributed on the base: material, information and finance flows. The author also shows a diagram of the distribution channels, taking into account the effect of distribution points at various stages of the decision making process consumer purchase. This prompted a further stage in the decision-making process - the stage of registration of the order by the consumer.

Key words: distribution channels, logistics, material flow, information flow, cash flow, flows in the distribution channels, the distribution system, the process of making purchasing decisions, omni-channel distribution strategy.

Вступ. Однією з важливих особливостей сучасних економічних систем $\epsilon$ підвищення значення і відповідно уваги до процесу розподілу продукції та послуг як на промисловому так і на споживчому ринках Проблемами формування каналів розподілу та управління ними займалися такі зарубіжні автори як: Л. Горчельс, Е. Марін, Ч. Уест [2], Д. Джоббер, Д. Ланкастер [3], Л.В. Штерн, А.І Ель-Ансарі, Е.Т. Кофлан [11]. Щодо вітчизняних спеціалістів 3 логістики та маркетингової політики розподілу слід виділити: С.Ю. Бондаренко, А.В. Войчак [1], О.В. Зозульов, С.О. Солнцев [4], О.Л. Каніщенко [5], О.О. Комяков [5,6], С.В. Крикавський [7,8], Н.С. Косар, А. Чубала [8], В.П. Пилипчук, П.В. Непша [9], В.В. Стадніченко [10], В.Г. Щербак [12]. В роботах зазначених авторів висвітлені базові теоретичні положення. Проте, сучасні світові тенденції щодо розподілу та практика використання нових, так званих омні-канальних стратегій розподілу потребують подальшого розвитку зазначених положень i формування вдосконаленого підгрунтя для їх розробки. Класичне розуміння каналів розподілу як сукупності фізичних та юридичних осіб, що приймають участь в доведенні продукції до споживача, стає дещо обмеженим і все менше відповідає дійсності. В першу чергу це пов'язано із розвитком імформаційнокомп'ютерних технологій і переміщенням бізнесу в онлайновий простір. Саме даний факт потребує більшої деталізації у розумінні поняття каналу розподілу. Тобто виходить така ситуація коли одна і та сама фізична чи юридична особа сама може мати декілька каналів по яким рухаються як матеріальні так i інформаційні потоки щодо доведення продукції до споживача. При цьому все більше значення отримує саме інформаційний потік, як складова процесу розподілу. В статі пропонується зміщення акценту від суб’єктної орієнтації, щодо каналів розподілу до вузлової орієнтації. 
Постановка завдання. Основною метою дослідження є розроблення вузлового відходу щодо каналів розподілу. Запропонований підхід має стати логічним підгрунтям для розроблення омні-канальних стратегій розподілу.

Методологія. Методологічною базою дослідження слугували фундаментальні положення економічної теорії, менеджменту та маркетингу. В роботі було використано такі загальнонаукові методи дослідження, як порівняння, узагальнення, аналіз та синтез. Застосовано табличні та графічні методи.

Результати дослідження. Перш ніж перейти до розроблення нового підходу пропонується розпочати із визначень поняття каналу розподілу різними вченими. I треба зазначити, що як вітчизняні так і зарубіжні автори пропонують достатньо схожі визначення, які мають яскраво виражену суб'єктну орієнтацію. В таблиці зазначені основні розповсюджені на сьогодні визначення каналу розподілу.

Таблиця

Визначення каналів розподілу зарубіжними та вітчизняними авторами

\begin{tabular}{|l|l|}
\hline \multicolumn{1}{|c|}{ Автори } & \multicolumn{1}{|c|}{ Визначення } \\
\hline $\begin{array}{l}\text { Л.В. Штерн, А.І Ель- } \\
\text { Ансарі, Е.Т. Кофлан }\end{array}$ & $\begin{array}{l}\text { Єднає ряд взаємопов'язаних організацій і агенцій, задача яких } \\
\text { полягає в переміщенні чого-небудь, що має споживчу цінність із } \\
\text { пункту винайдення, добування або виробництва до пункту } \\
\text { споживання [11]. }\end{array}$ \\
\hline К. Уотні & $\begin{array}{l}\text { Між організаційна система, залучена до задач створення продукції і } \\
\text { послуги, доступних для споживачів [9] }\end{array}$ \\
\hline Є.П. Голубков & Шлях, по якому товари рухаються від виробника до споживача [9] \\
\hline $\begin{array}{l}\text { С.В. Крикавський, } \\
\text { Н.С. Косар, } \\
\text { А. Чубала }\end{array}$ & $\begin{array}{l}\text { Сукупність незалежних організацій (посередників), які беруть } \\
\text { участь у просуванні товару чи послуги від виробника до споживача, } \\
\text { який використовую цей товар для безпосереднього споживання чи } \\
\text { для виробництва інших товарів [8]. }\end{array}$ \\
\hline
\end{tabular}

Продовження табл. 1

\begin{tabular}{|c|c|}
\hline О.О. Комяков & $\begin{array}{l}\text { Визначене поєднання різних ланок i типів посередників, які } \\
\text { здійснюють функції і потоки розподілу [5]. }\end{array}$ \\
\hline $\begin{array}{l}\text { Ф. Котлер, } \\
\text { В.Г. Щербак }\end{array}$ & 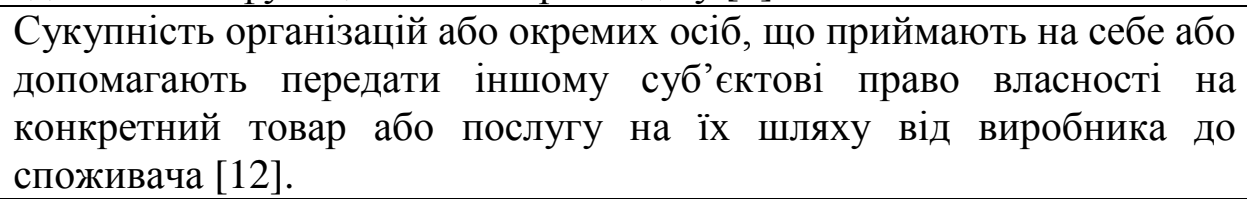 \\
\hline $\begin{array}{l}\text { С.Ю. Бондаренко, } \\
\text { А.В. Войчак, } \\
\text { А.Ф. Павленко }\end{array}$ & $\begin{array}{l}\text { маршрут, за яким продукція переміщується від місць виробництва } \\
\text { чи видобутку до місць споживання чи використання, зупиняючись у } \\
\text { певних пунктах, переходячи від одного власника до іншого, це } \\
\text { сукупність фірм або окремих осіб, які беруть на себе обов'язки чи } \\
\text { допомагають передати комусь іншому право власності на } \\
\text { товари (послуги) на їхньому шляху від виробника до споживача [1] }\end{array}$ \\
\hline
\end{tabular}

На основі вищезазначених визначень каналів розподілу з урахуванням сучасних тенденцій автором пропонується наступне визначення. 
Канал розподілу - це послідовність вузлів по яких в результаті здійснення операції із потоками розподілу відбувається доведення продукції (послуг) до споживача, які можуть знаходитись під контролем одного чи декількох ринкових суб'єктів.

Розуміння каналу як послідовності вузлів - є важливим аспектом в тому плані, що вже давно існує розуміння збуту як функції на підприємстві подібної до виробничої. Тобто, як у виробництві матеріальний потік проходить через послідовність цехів, де відбувається його трансформація в результаті якої з'являється маюча споживчу вартість корисна річ, так і у збуті має місце послідовність вузлів, що створюють додану вартість в результаті якої задовольняється потреба споживача. Зазначені збутові вузли подібно до виробничих так само являються пунктами витрат, які характеризуються різною пропускною можливістю та ефективністю.

Іншим важливим аспектом є розуміння, що у вузлах здійснюються операцій із усіма потоками розподілу, і для поглиблення такого розуміння пропонується більш детально розглянути потоки у процесі розподілу. Як відомо в маркетинговій політиці розподілу під потоком мається на увазі укрупнена сукупність функцій, і таких потоків виділяють вісім. При цьому в різних авторів можна відмітити деякі відмінності, частково пов'язані 3 різницею у перекладі, а частково і з різним розумінням. Так наприклад, Л.В. Штерн, А.І Ель-Ансарі, Е.Т. Кофлан пропонують класичний перелік [11,c. 25]:

- фізичне володіння;

- право власності;

- просування;

- переговори;

- фінансування;

- ризик;

- розміщення замовлення;

- оплата.

Для порівняння наведемо перелік найважливіших ринкових потоків, які переміщуються в каналі розподілу за Є.В. Крикавським, Н.С. Косар, А. Чубала [8, с. 18]:

- ринкова інформація (наприклад, зберігання i передавання інформації, яка стосується потенційних покупців, споживачів, конкурентів, цінової еластичності попиту),

- інформація 3 просування продукції (наприклад, передавання переконливої, заохочувальної до закупівлі інформації про запропоновані продукти), 
- контакти (наприклад, відшкодування потенційних покупців, встановлення умов купівлі-продажу з метою укладення угоди і передавання права власності на продукти),

- замовлення (наприклад, передавання інформації про намір закупівлі певної партії продуктів),

- платежі (наприклад, регулювання від імені покупців заборгованостей банками, фінансування запасів),

- право власності (наприклад, реальне передавання права власності або користування продуктом від одного учасника каналу до другого),

- ризик (наприклад, перейняття ризику, пов'язане 3 фінансуванням запасів, реалізацією продуктів, які переміщуються через канал, а також отриманням заборгованостей).

Цікаво, що в логістиці виділяють більш укрупнені потоки, а саме: матеріальний, інформаційний і фінансовий, до того ж ще зазначають потік сервісу. Дивним є факт, що саме сервісний потік відсутній в вище згаданих класифікаціях провідних спеціалістів 3 каналів розподілу, особливо враховуючи той факт, що у сучасному світі саме сервіс отримує все більше значення.

Для того щоб запобігти плутанини, автором пропонується розрізняти основні, базові потоки:

- матеріальний,

- інформаційний,

- фінансовий;

та синтетичні, більш дрібні потоки:

- фізичне володіння і переміщення;

- право власності,

- сервіс,

- ризики,

- оплата,

- просування,

- контакти та переговори,

- оформлення замовлення.

Синтетичними, зазначені 8 потоків розподілу можна вважати тому що вони більшою мірою пов'язані із декількома базовими потоками, складаються 3 них. На рис. 1. пропонується систематизація синтетичних потоків розподілу за базовими потоками за допомогою кругів Ейлера. 


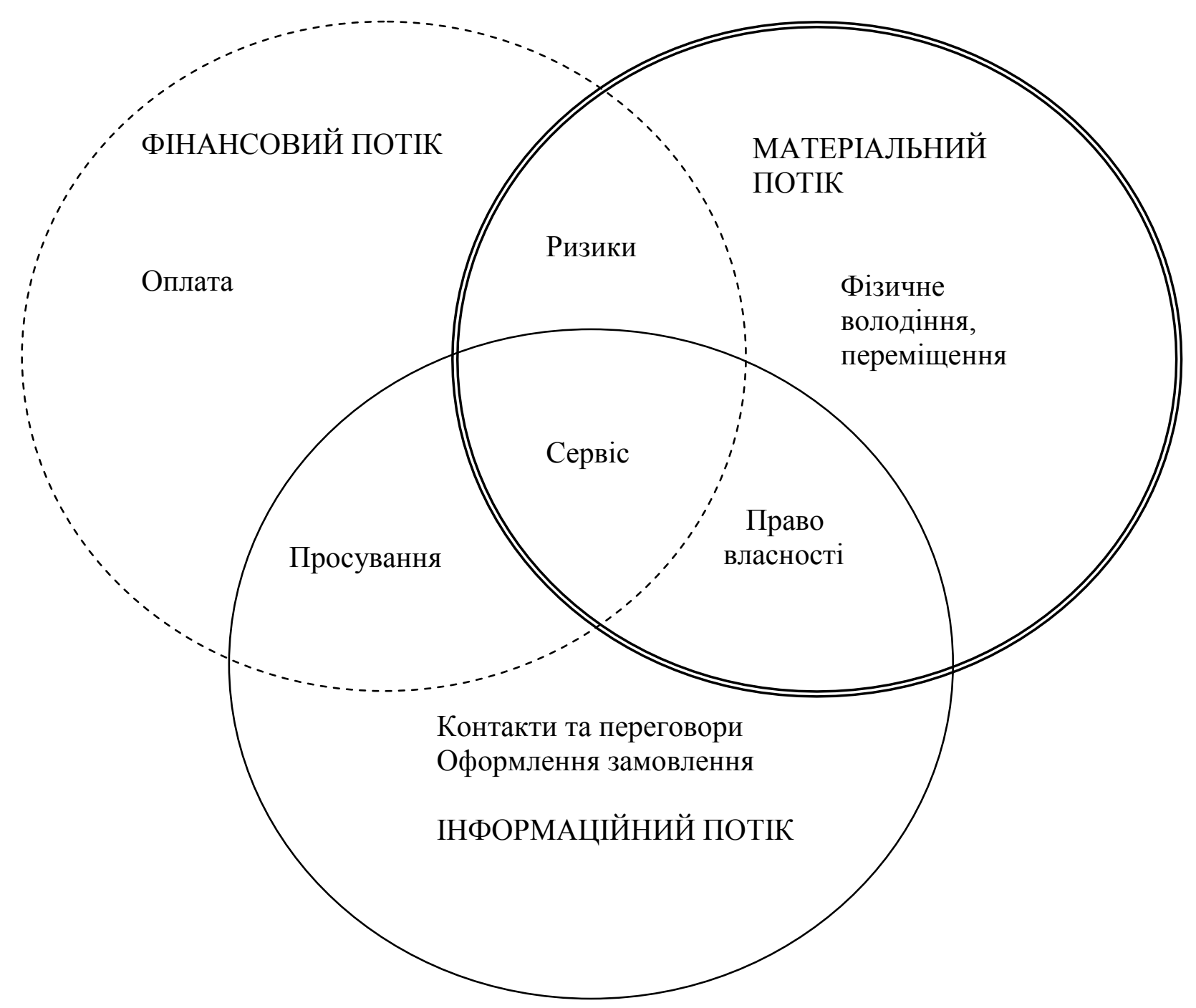

Рис. 1. Систематизація потоків в каналах розподілу, систематизовано автором на основі $[2,3,5]$ :

\begin{tabular}{ll}
\hline & - матеріальний потік; \\
$-\ldots-$ iнформаційний потік; & - фінансовий потік.
\end{tabular}

Останнім корисним доповненням у визначенні каналів розподілу $\epsilon$ зазначення що послідовність вузлів може перебувати як під контролем одного економічного суб'єкта так і під контролем декількох. Тобто, з одного боку не обов'язково ланка каналу розподілу повинна дорівнювати окремому економічному суб'єкту. 3 іншого боку, раніше можна було вважати, що наприклад, канал нульового рівня - один, наприклад фірмовий магазин. Але сьогодні, із розвитком Інтернет торгівлі одне і те ж саме підприємство може мати декілька каналів нульового рівня одночасно, при цьому вони мають бути достатньо інтегрованими і можуть розташовуватись як паралельно один одному, так і послідовно один за одним. Тобто компанія може застосовувати офлайн-магазин, Інтернет-магазин, продаж через мобільні пристрої, продаж 
через соціальні мережі, теле-маркетинг, продаж по телефону - i всі вони можуть бути по своїй суті різними каналами розподілу, тобто з них можуть складатися різні послідовності вузлів.

На рис. 2. наведено схему каналів розподілу, з якої ми можемо побачити як різні вузли приймають участь в процесі прийняття рішення про купівлю споживачем. Щодо процесу прийняття рішення - то прийнято виділяти 5 етапів [3, с. 65]:

- необхідність ідентифікації / усвідомлення наявності проблеми;

- збір інформації;

- оцінювання альтернативних варіантів і вибір найкращого рішення;

- вибір відповідного рішення (продукту);

- оцінювання прийнятого рішення після купівлі.

Дану послідовність етапів в процесі прийняття рішення про купівлю споживачем товарів та послуг логічно доповнити ще одним етапом оформлення замовлення. Справа в тому, що при купівлі продукції попереднього вибору та особливого попиту, тобто продукції, що дорого коштує, споживачу притаманний розрив у часі між прийняттям рішення про купівлю (4 етап за Д. Джоббер, Д. Ланкастер) і безпосереднім здійсненням покупки. До того ж між оформленням замовлення і отримання продукції в користування теж може бути розрив у часі. Таким чином рис. 2. пропонується доповнити 5-м етапом - оформлення замовлення.

Зі схеми можна побачити, як при купівлі, наприклад, орг. техніки споживач проходить наступні стадії за допомогою вузлів розподілу.

1. Спочатку усвідомлює потребу за допомогою соціальних мереж.

2. Далі з онлайн-магазинів збирає інформацію щодо цін та якості продукції, яка може задовольнити потребу.

3-4. В офлайн-магазині, побачивши продукцію в реальному вигляді, остаточно оцінює варіанти і приймає рішення про купівлю. Проте із самою купівлею споживач може не поспішати з різних причин.

5. Щодо оформлення замовлення для споживача може бути найбільш зручним використання телефонного дзвінку.

6. В свою чергу, щодо реакції на купівлю, то робота сервісного центру та технічної підтримки може суттєво вплинути. 


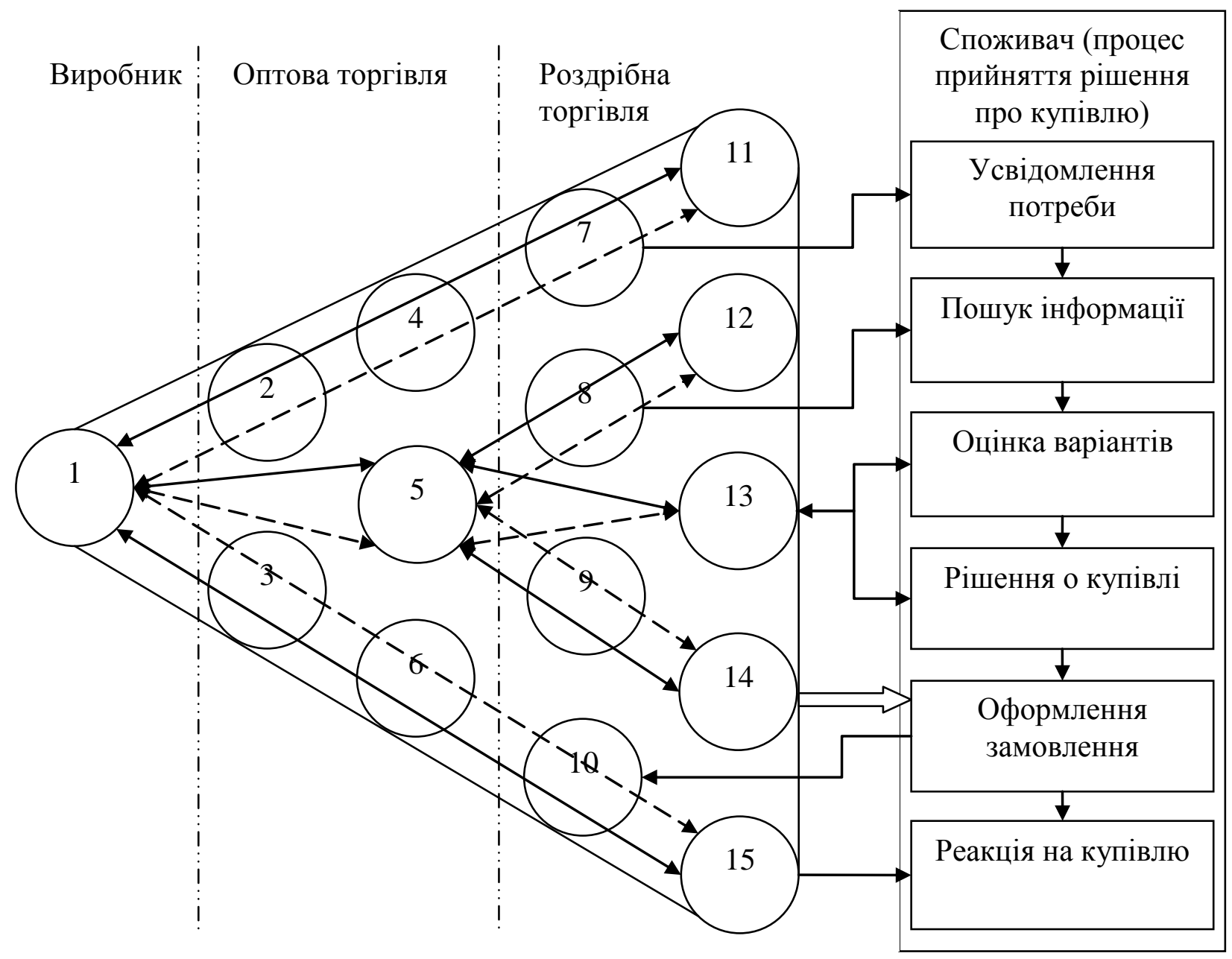

Рис. 2. Схема каналів розподілу [розроблено автором]:

1 - виробник; 2 - дистриб'ютор

4 - розподілчий центр 5 - комісіонер

7 - соц. мережа 8 - онлайн-магазин

10 - call-центр $\quad 11$ - склад

13 - офлайн-магазин $14-$ кур'єр

- матеріальний потік;

- інформаційний потік;

-...-..- - фінансовий потік.

Отже, можна зазначити, що вузловий підхід до каналів розподілу є більш гнучким і повніше відповідає принципам омні-канальності ('pmn1 греч. повнота, всеосяжність). Відомо, щодо омні-канальної стратегії, важливим принципом є можливість споживача легко, без втрати інформації, часу та коштів, переключатися між різними каналами. Розуміння вузлів у розподілі, прагнення вдосконалити вузькі місця і тим самим підвищити їх ефективність $\epsilon$ важливим кроком для розроблення дієвої стратегії розподілу. 
Висновки. Наукова новизна даної статті полягає у розвитку теоретичних засад щодо каналів розподілу. Автором запропоновано вузловий підхід, при якому канал розподілу розуміється як послідовність вузлів по яких в результаті здійснення операції із потоками розподілу відбувається доведення продукції (послуг) до споживача, які знаходяться під контролем одного чи декількох ринкових суб'єктів. Також в статті систематизовано логістичні потоки та потоки розподілу за допомогою кругів Ейлера. В результаті запропоновано схему каналів розподілу в рамках вузлового підходу, із урахуванням впливу окремих вузлів на різні стадії процесу прийняття рішення споживачем про купівлю. Подальшим напрямом дослідження буде апробація вузлового підходу при розробленні омніканальних стратегій розподілу на споживчих ринках.

\section{Література:}

1. Бондаренко С.Ю. Маркетингова політика розподілу та товарного руху : [монографія] / С.Ю. Бондаренко, А.В. Войчак. - К. : КДЕУ, 1994. — 19 с.

2. Горчельс Л. Управление каналами дистрибуции / Горчельс Л., Марин Э., Уэст Ч. - М.: Издательский дом Гребенникова, 2005 - 248 с.

3. Джоббер Д. Продажи и управление продажами : учеб. пособие / Д. Джоббер, Д. Ланкастер. - М. : ЮНИТИ-ДАНА, 2002. - 622 с.

4. Зозулев А.В. Маркетинговые исследования : теория, методология, статистика : учеб. пособие / А.В. Зозулев, С.А. Солнцев. - К. : Знання, 2008. - 643 с.

5. Каніщенко О.Л. Структуризація міжнародних каналів розподілу / О.Л. Каніщенко, О.О. Комяков // Економічний вісник НТУУ “КПІ" : ВПІ ВПК "Політехніка", 2009 р., - С. 276-280

6. Комяков О.О. До питань формування системи розподілу підприємства / О.О. Комяков // зб. наук. пр. "Економічний вісник" №1 : Вид. ПП "Екмо", 2004 р., - С. 338-341.

7. Крикавський Є.В. Логістичне управління : підручник / Є.В. Крикавський. - Л. : Видавництво Національного ун-ту "Львівська політехніка", 2005. - 683 с.

8. Крикавський Є.В. Маркетингова політика розподілу: навч. Посібник / Є.В. Крикавський, Н.С. Косар, А. Чубала. - 2-ге вид., зі змінами. - Львів: Видавництво Львівська політехніка, 2012. - 260 с. - (Серія «Світ маркетингу і логістики». - Вип. 1.).

9. Пилипчук В.П. Теоретико-методологічні аспекти маркетингових каналів розподілу / В.П. Пилипчук, П.В. Непша // Вчені записки : зб. наук. праць. «Київський нац. екон. ун-т ім. В. Гетьмана» [за ред. А.Ф. Павленко]. - К. : КНЕУ, вип. 9. - 2007. - 270 с. С. 7582.

10. Солнцев С.О., Структуризація дилерської мережі з метою підвищення її ефективності / С.О. Солнцев, Стадніченко В.В. // Вісник НУ «Львівська політехніка» : ВНУ «Львівська політехніка» - 2008. - №633. С.892-898.

11. Штерн Л.В. Маркетинговые каналы / Л.В. Штерн, А.И Эль-Ансари, Э.Т. Кофлан [пер. с англ. под ред. О.И. Медведь]. - М. : изд. дом „Вильямс”, 2002. - 624с.

12. Щербак В.Г. Маркетингова політика розподілу: навч. посібник / В.Г. Щербак. - Х.: ВД «IHЖЕК», 2004. - 176c. 